\title{
SEASONAL VARIATION OF FRESH WATER BLUE GREEN ALGAE IN GOSSAIGAON SUBDIVISION UNDER KOKRAJHAR DISTRICT
}

\section{Runuma Rabha Basumatary and Mautushi Das}

Department of Botany

University of Science and Technology, Meghalaya, India

Email: runumarabhabasumatary@gmail.com, moushg@gmail.com

How to cite this paper:

Basumatary, Runuma Rabha and Das, Mautushi (2021) Seasonal Variation Of Fresh Water Blue Green Algae in Gossaigaon Subdivision Under Kokrajhar District, Journal of Global Resources, Vol. 07 (02)

DOI:

10.46587/JGR.2021.v07i02.015
Abstract: The present studies were carried out of fresh water Blue Green Algae or Cyanophyceae in Gossaigaon subdivision of Kokrajhar district during 2017-18 and a total 76 water samples were collected covering the four seasons and 21 species were identified. All identified species were heterocystous filamentous forms. The highest no of species was found during monsoon followed by post monsoon, pre monsoon and winter respectively. It was determining the physicochemical characteristics of water. Beside this their occurrence, diversity and distribution in different seasons were interpreted with physico-chemical properties of water.

Keywords: Cyanophyceae, Diversity, Fresh water, Rivulariaceae, Seasonal Variation

Received: 18 April 2021

Reviewed: 25 May 2021

Revised: 04 June 2021

Final Accepted: 06 June 2021

OPEN O A C C ESS

Freely available Online www.isdesr.org 


\section{Introduction}

Blue green algae (Cyanobacteria or Cyanophyceae) are autotrophic simple colonizing microorganisms which are present throughout the world. These microorganisms are cosmopolitan and well adapted to any environment(Singh,2014). The low ratio of N-P favours the formation of bloom of cyanobacteria. They are ubiquitous and found in clean as well as polluted water (Kumar and Singh,1982) including crop lands (Peoples et al.,1995). They produced oxygen and have the capability to fix atmospheric nitrogen. Thus, they increase the productivity rate of crop plants. They are simple but ecologically important as primary producer. Rivulariaceae is one of the families of Cyanophyceae. The members of the family are heterocystous at the base and filaments tapered from the base which is wider to narrower at the tip. They form colonies by aggregation of hormogonia. The group as a whole occurs in environments with highly variable Potassium concentration. Nitrogen fixation in Rivulariaceae is highest when Potassium content is high. There are some workers (Barman, Deka, and Barma,2015;Nath,2012; Paul and Rout,2016; Gurumayum and Senapati, 2017; Dihingia, and Baruah, 2017; Sarma, and Rout, 2017 ) who have studied on these algae in various districts of Assam. But in lower Assam, Kokrajhar is one the district where it is still neglected of studying in this field.

\section{Materials and Methods}

The present study was carried out in Gossaigaon sub division under Kokrajhar district. Phytogeographically the study area has a total of $1287.70 \mathrm{~km}$ geographical area. It is situated at the latitude of $26.4371^{\circ} \mathrm{N}$ and longitude of $89.9767^{\circ} \mathrm{E}$. The maximum average temperature of the area is $30.18^{\circ} \mathrm{C}$ and minimum is $18.94^{\circ} \mathrm{C}$. The average rainfall is $297.93 \mathrm{~mm}$. The algal samples were collected from the all kinds of water like polluted and non-polluted water during the year 2017 to 2018 covering three different sampling stations in the area of present study. The sampling stations were Saraibil (Station-1), Gossaigaon (Station-2) and Grahampur (Station-3).

\section{i. Collection, Identification and Preservation of the Samples}

The field collection was made randomly from all aquatic environments covering all the four seasons i.e., pre-monsoon, monsoon, re-treating monsoon and winter (Barthakur, 1986) in three different sampling stations of Gossaigaon sub-division of Kokrjhar district (BTAD), Assam. The samples were collected in to a properly labeled vials with habitat water to its $1 / 3$ capacity and not down the occurrence and distribution of species and other distinguishing characters. The collected specimens were directly carried to the laboratory and observed in compound microscope as early as possible. The species were identified following the monograph of Desikachary (1959) and Anand (1989) and rest of the specimens preserved with 4 percent formalin for further use.

\section{ii. Physico-Chemical Properties of Water}

The physico-chemical properties of water were estimated according to the procedure of APHA (2005). The temperature and $\mathrm{pH}$ were determined by using thermometer and digital $\mathrm{pH}$ meter at the spot. The other parameters like-phosphate, potassium and available nitrogen, BOD, DO, COD were estimated according to procedure in APHA (2005).

\section{iii. Measures of Seasonal Diversity}

Species diversity of the members of Rvulariaceae in the study area were subjected to diversity analysis using different indices like Shannon-Weiner index $(H)$ after Shannon-Weiner (1949); Simpson Dominance index (D); Simpson index of diversity (1- D) (Simpson, 1949); Pielous Evenness (Pielou, 1966). 
Shannon-Weiner index $(\mathrm{H} /)$

Where,

$$
\mathrm{H}=-\Sigma \mathrm{Pi} \log 2 \mathrm{Pi}
$$

$$
\begin{aligned}
& \mathrm{H}=\text { Shannon-Weiner index } \\
& \mathrm{Pi}=\mathrm{ni} / \mathrm{N} \\
& \Sigma=\text { Sum } \\
& \mathrm{ni}=\text { Number of individuals of each species in the sample. } \\
& \mathrm{N}=\text { Total number of individuals of all species in the sample. }
\end{aligned}
$$

\section{Simpson's Diversity Indices}

Simpson's diversity index is a measure of diversity. It takes into account the number of species present, as well as the abundance of each species.

\section{a. Simpson's index of dominance (D)}

Where,

$$
\mathrm{D}=\Sigma[\mathrm{ni}(\mathrm{ni}-1) / \mathrm{N}(\mathrm{N}-1)]
$$

$\mathrm{ni}=$ The total number of individuals of a particular species.

$\mathrm{N}=$ the total number of individuals of all species.

b. Simpson's index of diversity (1-D):

\section{Pielou's Evenness (E)}

From D Simpson's Diversity Index, $1-\mathrm{D}$, is calculated.

Where,

$$
\mathrm{J}=\mathrm{H} / \log 2 \mathrm{~S}
$$

' $\mathrm{H}$ ' is the Shannon Weiner index and ' $\mathrm{S}$ ' is the number of species

\section{iv. Statistical Analysis}

All the statistical analysis was calculated using software Microsoft Excel 2010 and different diversity indices were estimated using software program PAST3.

\section{Results and Discussion}

The total of 21 species of Cyanophyceae of the family Rivulariaceae belonging to 4 genera were collected and identified from 76 samples. The identified species are listed in the table 1 below. From the table, it was evident that maximum occurrence of species was in the genus Calothrix (11 species) followed by Gloeotrichia (7 species), Rivularia (3 species) and Dichothrix (1 species).

Table 01: List of Identified Species of the Family Rivulariaceae

\begin{tabular}{|c|l|c|l|}
\hline$\#$ & Name of species & $\#$ & Name of species \\
\hline 1 & Calothrix brevissima & 12 & Gloeotrichia echinulata \\
\hline 2 & Calothrix brevissima var. moniliforme & 13 & Gloeotrichia ghosei \\
\hline 3 & Calothrix elenkinii & 14 & Gloeotrichia intermedia \\
\hline 4 & Calothrix fusca & 15 & Gloeotrichia longicauda \\
\hline 5 & Calothrix gloecola & 16 & Gloeotrichia natans \\
\hline 6 & Calothrix marchica & 17 & Gloeotrichia pisum \\
\hline 7 & Calothrix membranacea & 18 & Gloeotrichia raciborskii \\
\hline 8 & Calothrix parietina & 19 & Rivularia aquatica \\
\hline 9 & Calothrix scytonemicola & 20 & Rivularia beccariana \\
\hline 10 & Calothrix wembraerensis & 21 & Rivularia globiceps \\
\hline 11 & Dichothrix gypsophila & & \\
\hline
\end{tabular}

\section{Relative Abundance}

During the study period Rivularia globiceps was most abundant (table-2a) over others collected from the station-1 (Saraibil) while Gloeotrichia longicauda was found to be least abundant of the others. Similarly, Calothrix membranacea, Rivularia aquatic and Gloeotrichia ghosei were found most abundant in the study station-2 (Gossaigaon) while Calothrix elenkinii, Gloeotrichia 
natans and Gloeotrichia raciborskii were found least abundant in study station-2. In study station-3 (Grahampur), Calothrix membranacea was reported to be most abundant over others and Calothrix wembraerensis was found least abundant during the study period.

Table 02(a): Seasonal Variation of Rivulariaceae in Station-1 (Saraibil)

\begin{tabular}{|c|l|c|c|c|c|c|c|}
\hline$\#$ & \multicolumn{1}{|c|}{ Name of species } & PM & M & RM & W & Total & RA (\%) \\
\hline 1 & Calothrix scytonemicola & 0 & 1 & 2 & 0 & 3 & 11.11 \\
\hline 2 & Calothrix brevissima & 3 & 0 & 1 & 1 & 5 & 18.51 \\
\hline 3 & Calothrix gloecola & 1 & 0 & 2 & 0 & 3 & 11.11 \\
\hline 4 & Rivularia aquatica & 2 & 1 & 2 & 0 & 5 & 18.51 \\
\hline 5 & Rivularia globiceps & 0 & 4 & 0 & 2 & 6 & $\mathbf{2 2 . 2 2}$ \\
\hline 6 & Rivularia beccariana & 2 & 1 & 0 & 1 & 4 & 14.81 \\
\hline 7 & Gloeotrichia longicauda & 0 & 0 & 1 & 0 & 1 & $\mathbf{0 3 . 7 0}$ \\
\hline
\end{tabular}

$\mathrm{PM}=$ Pre-Monsoon; $\mathrm{M}=$ Monsoon; $\mathrm{RM}=$ Retreating Monsoon; $\mathrm{W}=$ Winter; RA= Relative Abundance

Table 02(b): Seasonal Variation of Rivulariaceae in Station-2 (Gossaigaon)

\begin{tabular}{|c|l|r|r|r|r|r|c|}
\hline$\#$ & \multicolumn{1}{|c|}{ Name of species } & PM & M & RM & W & Total & RA (\%) \\
\hline 1 & Calothrix brevissima & 0 & 0 & 1 & 1 & 2 & 6.06 \\
\hline 2 & Calothrix elenkinii & 1 & 0 & 0 & 0 & 1 & $\mathbf{3 . 0 3}$ \\
\hline 3 & Calothrix fusca & 0 & 3 & 1 & 0 & 4 & 12.12 \\
\hline 4 & Calothrix membranacea & 1 & 1 & 0 & 3 & 5 & $\mathbf{1 5 . 1 5}$ \\
\hline 5 & Calothrix periatina & 1 & 0 & 1 & 1 & 3 & 9.09 \\
\hline 6 & Dichothrix gypsophila & 0 & 0 & 1 & 0 & 1 & 6.06 \\
\hline 7 & Rivularia aquatica & 1 & 1 & 1 & 2 & 5 & $\mathbf{1 5 . 1 5}$ \\
\hline 8 & Gloeotrichia echinulata & 0 & 0 & 0 & 2 & 2 & 6.06 \\
\hline 9 & Gloeotrichia ghosei & 3 & 0 & 2 & 0 & 5 & $\mathbf{1 5 . 1 5}$ \\
\hline 10 & Gloeotrichia intermedia & 0 & 1 & 2 & 0 & 3 & 9.09 \\
\hline 11 & Gloeotrichia natans & 0 & 1 & 0 & 0 & 1 & $\mathbf{3 . 0 3}$ \\
\hline 12 & Gloeotrichia raciborskii & 2 & 0 & 0 & 1 & 1 & $\mathbf{3 . 0 3}$ \\
\hline
\end{tabular}

$\mathrm{PM}=$ Pre-Monsoon; $\mathrm{M}=$ Monsoon; $\mathrm{RM}=$ Retreating Monsoon; $\mathrm{W}=$ Winter; $\mathrm{RA}=$ Relative Abundance

Table 02(c): Seasonal Variation of Rivulariaceae in Station-3 (Grahampur)

\begin{tabular}{|c|l|c|c|c|c|c|c|}
\hline Name of species & PM & M & RM & W & Total & RA (\%) \\
\hline 1 & Calothrix brevissima var.moniliforme & 1 & 0 & 3 & 1 & 5 & 13.15 \\
\hline 2 & Calothrix marchica & 0 & 1 & 1 & 0 & 2 & 5.26 \\
\hline 3 & Calothrix membranacea & 6 & 0 & 1 & 0 & 7 & $\mathbf{1 8 . 4 2}$ \\
\hline 4 & Calothrix parietina & 0 & 2 & 0 & 1 & 3 & 7.89 \\
\hline 5 & Calothrix scytonemicola & 1 & 0 & 1 & 3 & 5 & 13.15 \\
\hline 6 & Calothrix wembraerensis & 0 & 0 & 0 & 1 & 1 & $\mathbf{2 . 6 3}$ \\
\hline 7 & Rivularia aquatica & 1 & 2 & 1 & 2 & 6 & 15.78 \\
\hline 8 & Gloeotrichia natans & 0 & 4 & 1 & 0 & 5 & 13.15 \\
\hline 9 & Gloeotrichia pisum & 1 & 1 & 2 & 0 & 4 & 10.52 \\
\hline
\end{tabular}

$\mathrm{PM}=$ Pre-Monsoon; $\mathrm{M}=$ Monsoon; $\mathrm{RM}=$ Retreating Monsoon; $\mathrm{W}=$ Winter; RA= Relative Abundance

\section{Species Richness, Abundance and Diversity Indices}

Species richness, relative abundance and diversity of a particular area directly correlated with the environmental features of that area. As these parameters fluctuate throughout the year and seasonal variation is also observed in species richness, relative abundance and diversity. During the study period seasonal as well as spatial variation in species richness, abundance and diversity were observed in the study area. All the results have been discussed below.

\section{i. Station-1 (Saraibil)}

During the study period, species abundance was ranged between 04 and 08, minimum during winter and maximum in pre-monsoon and retreating monsoon. Species richness was ranged between 03 and 05 , minimum during winter season and maximum in retreating monsoon 
season. Shannon-Weiner index $(\mathrm{H})$ was ranged between 1.04 and 1.56 minimum during winter and maximum in retreating monsoon. Simpson's index of dominance (D) was ranged between 0.21 and 0.38 minimum during retreating monsoon and maximum in monsoon seasons. Simpson's index of diversity was ranged between 0.61 and 0.78 , maximum during retreating monsoon and minimum in monsoon seasons. Evenness $(E)$ was ranged between 0.79 and 0.95 minimum during monsoon and maximum in retreating monsoon season.

\section{ii. Study Station-2 (Gossaigaon)}

In Study Station-2 (Gossaigaon) species abundance was ranged between 07 and 10, minimum during monsoon and maximum in winter. Species richness was ranged between 05 and 07 minimum during monsoon and maximum in retreating monsoon season. Shannon-Weiner index $(\mathrm{H})$ was ranged between 1.47 and 1.88, minimum during monsoon and maximum in retreating monsoon. Simpson's index of dominance (D) was ranged between 0.16 and 0.26 minimum during retreating monsoon and maximum in monsoon season. Simpson's index of diversity was ranged between 0.73 and 0.83 , maximum during retreating monsoon and minimum during monsoon. Evenness $(\mathrm{E})$ was ranged between 0.87 and 0.94 , minimum during monsoon and maximum in retreating monsoon and winter seasons.

\section{iii. Study Station-3 (Grahampur)}

During the study period, species abundance was ranged between 08 and 10, minimum during winter and maximum during rest of the seasons. Species richness was ranged between 05 and 07 maximum during retreating monsoon and minimum during rest of the seasons. Shannon-Weiner index $(\mathrm{H})$ was ranged between 1.22 and 1.83, minimum during pre-monsoon and maximum in retreating monsoon. Simpson's index of dominance (D) was ranged between 0.18 and 0.40 , minimum during retreating monsoon and maximum in pre-monsoon season. Simpson's index of diversity was ranged between 0.60 and 0.82 , minimum during premonsoon and maximum in retreating monsoon season. Evenness $(E)$ was ranged between 0.68 and 0.89 minimum during pre-monsoon and maximum during retreating monsoon and winter seasons.

Table 03: Station wise Diversity Indices of Rivulariaceae

\begin{tabular}{|c|c|c|c|c|c|c|c|}
\hline \multirow{3}{*}{ Seasons } & \multirow{3}{*}{ Stations } & \multicolumn{6}{|c|}{ Diversity Indices } \\
\hline & & \multirow{2}{*}{$\begin{array}{c}\text { No. of } \\
\text { species } \\
\text { (Richness) }\end{array}$} & \multirow{2}{*}{$\begin{array}{c}\text { No. of } \\
\text { Individuals } \\
(\mathrm{N}) \\
\text { (Species } \\
\text { Abundance) }\end{array}$} & \multirow{2}{*}{$\begin{array}{c}\text { Species } \\
\text { Diversity } \\
\text { (H) } \\
\text { Shannon_H }\end{array}$} & \multicolumn{2}{|c|}{$\begin{array}{l}\text { Simpson's Diversity } \\
\text { Indices }\end{array}$} & \multirow[b]{2}{*}{$\begin{array}{l}\text { Evenness } \\
\text { (E) }\end{array}$} \\
\hline & & & & & $\begin{array}{l}\text { Simpson's } \\
\text { Dominance } \\
\text { (D) }\end{array}$ & $\begin{array}{c}\text { Simpson's } \\
\text { Diversity } \\
\text { (1-D) }\end{array}$ & \\
\hline \multirow[t]{3}{*}{ PM } & 1 & 04 & 08 & 1.32 & 0.28 & 0.71 & 0.93 \\
\hline & 2 & 06 & 09 & 1.67 & 0.20 & 0.79 & 0.89 \\
\hline & 3 & 05 & 10 & 1.22 & 0.40 & 0.60 & 0.68 \\
\hline \multirow[t]{3}{*}{ Mn } & 1 & 04 & 07 & 1.15 & 0.38 & 0.61 & 0.79 \\
\hline & 2 & 05 & 07 & 1.47 & 0.26 & 0.73 & 0.87 \\
\hline & 3 & 05 & 10 & 1.47 & 0.26 & 0.74 & 0.87 \\
\hline \multirow[t]{3}{*}{ RM } & 1 & 05 & 08 & 1.56 & 0.21 & 0.78 & 0.95 \\
\hline & 2 & 07 & 09 & 1.88 & 0.16 & 0.83 & 0.94 \\
\hline & 3 & 07 & 10 & 1.83 & 0.18 & 0.82 & 0.89 \\
\hline \multirow[t]{3}{*}{ Wn } & 1 & 03 & 04 & 1.04 & 0.37 & 0.62 & 0.94 \\
\hline & 2 & 06 & 10 & 1.69 & 0.20 & 0.80 & 0.94 \\
\hline & 3 & 05 & 8 & 1.49 & 0.25 & 0.75 & 0.89 \\
\hline
\end{tabular}

$\mathrm{PM}=$ Pre-monsoon, $\mathrm{Mn}=$ Monsoon, $\mathrm{RM}=$ Retreating monsoon, $\mathrm{Wn}=$ winter; $1=$ Saraibil, $2=$ Gossaigaon, $3=$ Grahampur

\section{Water Quality}

Results on the analysis of different chemical parameters of aquatic habitat of Rivulariaceae have been depicted in the table-3 below. Station wise measure on average $\mathrm{pH}$ shows that $\mathrm{pH}$ of aquatic habitat ranged between $6.67 \pm 0.93$ and $6.75 \pm 0.36$, minimum in station-3 (Grahampur) and maximum in station-1(Saraibil) during entire period of study. During the study 
period average Biological Oxygen Demand (BOD) of the study stations ranged between $4.81 \pm 1.12$ and $6.36 \pm 1.77$, minimum in station-1 (Saraibil) and maximum in station-2 (Gossaigaon). Aerobic decomposition of any organic matter is carrying out by microorganism (Jain et al.,1997). It was observed that high BOD was found in station 2 , which is a semi urban area and found rich in organic matter as municipal and domestic waste water, forest and agricultural litters are drained off to this habitat due to heavy rainfall. Chemical Oxygen Demand (COD) content ranged between $12.76 \pm 2.36$ and $16.95 \pm 2.70$, minimum in station-3 (Grahampur) and maximum in station-2 (Gossaigaon).

\begin{tabular}{|c|c|c|c|c|c|c|c|}
\hline \multirow[b]{2}{*}{ Stations } & \multicolumn{7}{|c|}{ Water Parameters } \\
\hline & PH & $\begin{array}{l}\text { BOD } \\
(\mathrm{mg} / \mathrm{l})\end{array}$ & $\begin{array}{l}\text { COD } \\
(\mathrm{mg} / \mathrm{l})\end{array}$ & $\begin{array}{c}\mathrm{DO} \\
(\mathrm{mg} / \mathrm{l})\end{array}$ & $\begin{array}{c}\text { Nitrate } \\
(\mathrm{mg} / \mathrm{l})\end{array}$ & $\begin{array}{c}\text { Phosphate } \\
\text { (mg/l) }\end{array}$ & $\begin{array}{c}\text { Potassium } \\
(\mathrm{mg} / \mathrm{l})\end{array}$ \\
\hline 1 & $6.75 \pm 0.36$ & $4.81 \pm 1.12$ & $14.71 \pm 3.63$ & $5.05 \pm 0.83$ & $4.35 \pm 0.71$ & $1.63 \pm 0.45$ & $5.41 \pm 0.73$ \\
\hline 2 & & & & & & & .12 \\
\hline 3 & $6.67 \pm 0.93$ & $5.03 \pm 1.24$ & $12.76 \pm 2.36$ & $7.35 \pm 2.09$ & $5.05 \pm 1.82$ & $1.61 \pm 0.36$ & $7.16 \pm 1.80$ \\
\hline
\end{tabular}

1= Saraibil; 2= Gossaigaon; 3= Grahampur

The average Dissolved Oxygen (DO) content of the aquatic habitat ranged between $5.05 \pm 0.83$ and $7.35 \pm 2.09$, minimum in station-1 (Saraibil) and maximum in station-3 (Grahampur). The average nitrate content of the water bodies of the study area ranged between $4.35 \pm 0.71$ and $5.06 \pm 1.21$ during the study period, minimum in station- 1 (Saraibil) and maximum in station-2 (Gossaigaon). The average phosphate content ranged between $1.26 \pm 0.12$ and $1.63 \pm 0.45$ during the study period, minimum in station-2 (Gossaigaon) and maximum in station-1 (Saraibil). The average potassium content of the blue green algal habitat of the study area ranged between $5.41 \pm 0.73$ and $7.16 \pm 1.80$ during the study period, minimum in station-1 (Saraibil) and maximum in station-3 (Grahampur).

\section{PHOTOGRAPHIC PLATE}
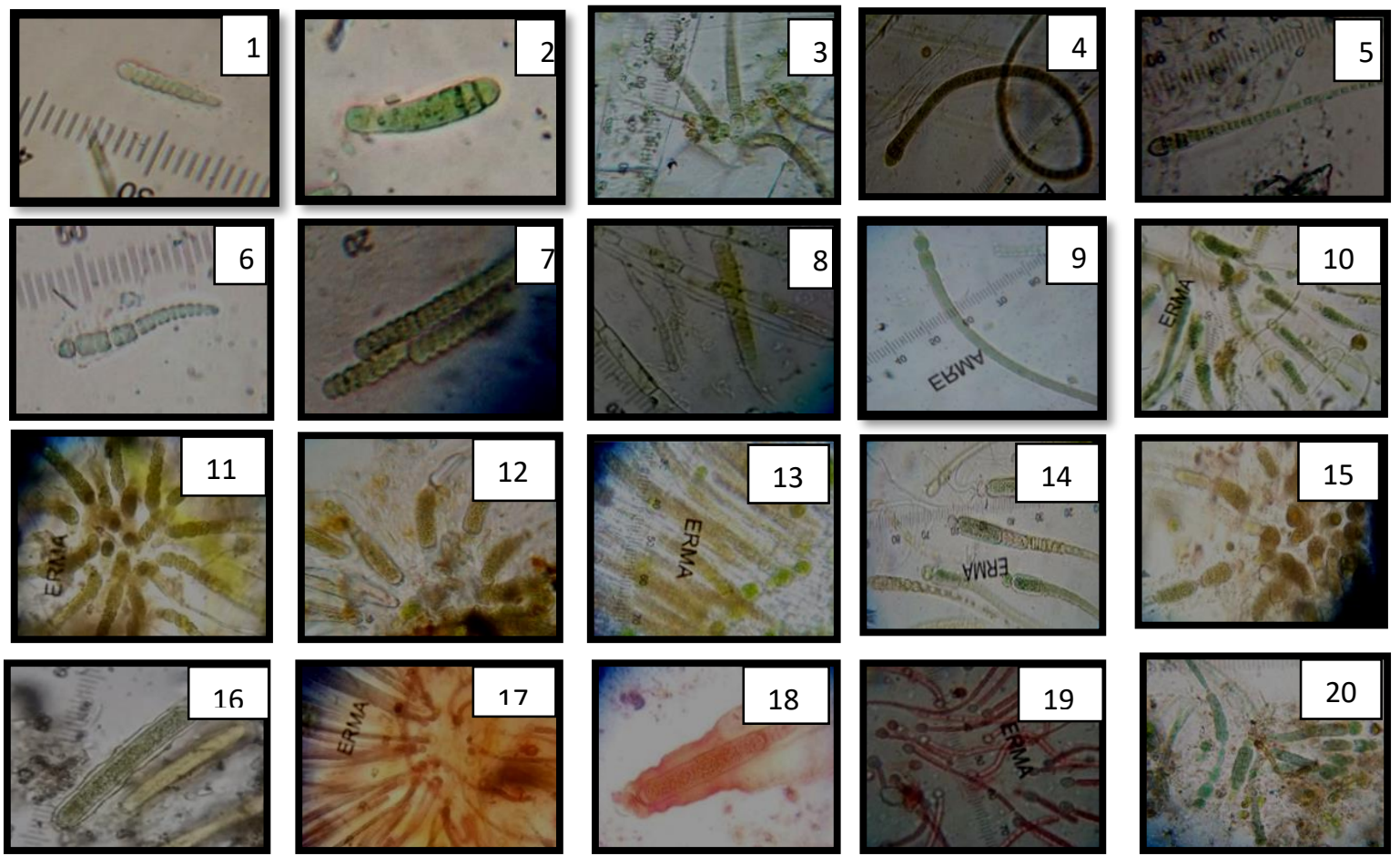

Figures.1) Calothrix brevissima West, G.S., 2)Calothrix brevissima var. moniliforme Ghose orth. Mut.,3) Calothrix elenkinii Kossinskaja.,4) Calothrix fusca (Kütz.) Bornet et Flahault.5) Calothrix gloeocola Skuja.,6) Calothrix marchica Lemmermann.,7)Calothrix membranacea Schmidle.,8)Calothrix parietina Thuret ex Born .et Flah.,9)Calothrix scytonemicola Tilden.10) Dichothrix gypsophila (Kütz.) Born . et Flah.11) Gloeotrichia echinulata (j.e.)Smith P. Richter.,12) Gloeotrichia ghosei Singh, R.N.,13) Calothrix wembaerensis Hieron . et Schmidle.,14) Gloeotrichia intermedia var. kanwaensis Rao, C. B., 15) Gloeotrichia longicauda Schmidle.,16) Gloeotrichia natan Rabenhorst ex Born. et Flah.17) Gloeotrichia pisum Thuret ex Born. et Flah. 18) Gloeotrichia raciborskii var longispora Rao, C.B.,19) Rivularia aquatica De Wilde.,20) Rivularia beccariana (De Not) Born. Et Flah.21) Rivularia globiceps West, G.S., 


\section{Conclusion}

The water bodies are the principal habitats for the blue green algae in this area and are rich in organic matter as most of the forest and agricultural litters are drained off to these habitats due to heavy rainfall during the monsoon season. The $\mathrm{pH}$ ranges of the present study area are slightly basic which, perhaps, favours the growth and development of most of the species. $\mathrm{pH}$ is an important factor which are determining the productivity in any ecosystem(Singh et al.,2009). Occurrence and distribution of the Cyanophyceae is related to the organic matter and $\mathrm{pH}$ of the habitat in which they grow. The change of population of Cyanophyceae in the present study may be due to the water availability, temperature( )and light intensity ( ) which are important factors to the growth of cyanobacteria.

\section{References}

1. Anand, N. (1989). Handbook of Blue-Green Algae (of Rice-Fields of South India), Bishen Singh Mahendra Pal Singh. Dehradun.

2. APHA (American Public Health Association), (2005). Standard Methods for the Examination of Water and Wastewater. $21^{\text {th }}$ edition. American Water Works Association Water Pollution Control Federation, New York.

3. Barman, D., Deka, S.J. and Barma B. (2015). Seasonal Diversity and Habitat characteristics of Algae of Wetlands in the West Garo Hills, Meghalaya, India. Research Journal of Recent Sciences.Vol.4: 274-279.

4. Desikachary, T.V (1959). Cyanophyta, Monograph, Indian Council of Agricultural Research, New Delhi .

5. Dihingia, J. and Baruah, P.P. (2017). Studies on $\mathrm{N}_{2}$-fixing cyanobacterial diversity and its seasonal variation in the rice fields soils of Brahmaputra floodplain of Kamrup District Assam. Journal of Algal Biomass Utilization. 8(3):40-49.

6. Gurumayum, S. and Senapati, S.S. (2017). Exploration of Algal Varieties from Panikhaiti Area of Guwahati using Winograd sky Column. International Journal of Current Microbiology and Applied Sciences. 6(3). pp 1195-1204.

7. Jain, Y., Dhanija, S.K.S., Vijay, T.(1997): Ground water quality in coastal region of Andhra Pradesh. Indian Journal of Env. Health 39(3) 182-190.

8. Kumar, H.D and Singh, H.N.(1982): A Textbook on Algae. Affiliated East-West Press Pvt. Ltd., New Delhi.

9. Nath, D.C. (2012). of pesticide on the occurrence and distribution of blue green algae in the rice fields of Dhubri District, Assam, Ph.D. thesis, Gauhati University, Gauhati.

10. Paul, A. and Rout, J. (2016). Seasonal variation and algal diversity in the highly alkaline solid wastes from a paper mill in southern Assam (India). Int. J. of Pharm Bio Sci. 7(3): (B) 1274-1280.

11. Peoples, M.B., Herridge, D.F., Ladha, J.K. (1995). Biological nitrogen fixation: an efficient source of nitrogen for sustainable agricultural production . Plant Soil. 174:3-28.

12. Pielou, E.C.(1966). Species-diversity and pattern-diversity in the study of ecological succession. J. Theor. Biol., 10:370-383.

13. Sarma, P. and Rout, J. (2017). Colonisation of Oscillatoria on submerged polythene in domestic sewage water of Silchar town, Assam (India). Journal of Algal Biomass Utilization 8(4):135-144.

14. Shannon, C.E., and Weaver, W. (1949). The Mathematical Theory of Communication, Urbana: University of Illinois Press.

15. Simpson, E.H. (1949). Measurement of diversity. Nature, 163: 688.

16. Singh, A.K., Tiwari, R.K., Kanaujia, D. R., Mishra, P. (2009). Physico-chemical characteristics of Ganga river water at Varanasi. J. Ecobiol 25(1): 45-56.

17. Singh, J. S. (2014). Cyanobacteria: a vital bio-agent in eco-restoration of degraded lands and sustainable agriculture. Climate Change Environ Sustain, 2:133-137. 